\title{
APPENDIX Vв \\ Major officials of the Yogyakarta administration, 1755-1825
}

Bupati wedana of Madiun ${ }^{1}$

Pangéran Mangkudipura 1755-c. 1760

former Kartasura appointee related to the Kartasura court and descended from a line of former Kartasura bupati of Madiun with their residence at Wanasari in the southern part of Madiun town. Did not have the trust of Hamengkubuwana I.

Radèn Rongga Prawiradirja I

c. $1760-1784$

previously Kyai Tumenggung Wirasentika, brotherin-law and favourite of Hamengkubuwana I. Served as his army commander and given the military title of 'Rongga'. Known as the champion (gegedhug) of Sokawati.

Radèn Rongga Prawiradirja II 1784-June 1790, 27 October 1794-15 January 1796 also known as Radèn Rongga Mangundirja and Radèn Rongga dhongkol Maèspati - 'the early retired Radèn Rongga of Maospati', the last a reference to his residence $10 \mathrm{kms}$ to the west of Madiun, later the official seat of the bupati wedana under his son, Radèn Rongga Prawiradirja III, until December 1810. A son-in-law of Hamengkubuwana I known for his piety. Retired early from his position because of blindness.

Radèn Tumenggung June 1790-27 October 1794

Sasradiningrat I son-in-law of Hamengkubuwana II and father-in-law of the Yogya Crown Prince (later Hamengkubuwana III). Served as interim bupati wedana because of the incapacity of Radèn Rongga Prawiradirja II. Became senior bupati of Jipang-Rajegwesi until his death in May 1807.

1 Details taken from KITLV H 699, Rouffaer, 'Archiefstukken (diverse) over de vorstenlanden', loose notes on the bupati wedana of Madiun; Adam 1940:331-6. 
Radèn Rongga Prawiradirja III 14 January 1796-17 December 1810

son of Radèn Rongga Prawiradirja II and son-in-law of Hamengkubuwana II; killed in revolt 17-12-1810.

*Pangéran Dipakusuma 5 January 1811-1822 descended in the female line from Sunan Amangkurat III (1703-1708) and Radèn Mas Garendi (Sunan Kuning). Born in Ceylon. Acting bupati wedana until his death in 1822.

*Radèn Rongga

Prawirasentika

Pangéran Rongga

Prawiradiningrat

Pengulu ${ }^{2}$

Pekih Ibrahim (Dipaningrat I)

Muhamad Sapingi

Kyai Rahmanudin

Ketib Abuyamin, later Pengulu Kamalodiningrat
5 January 1811-February 1826 son of Radèn Rongga Prawiradirja I and son-in-law of Hamengkubuwana II. Acting bupati wedana until his dismissal for maladministration in 1826. Allowed to continue as bupati of Tunggul.

1822-1859

son of Radèn Rongga Prawiradirja III by Ratu Maduretna, a daughter of Hamengkubuwana II and Ratu Kedhaton. Acting bupati wedana with Radèn Rongga Prawirasentika 1822-1826. After 1826, became the first full bupati wedana of Madiun since the death of his father on 17-12-1810, and subsequently (1830) appointed to title of 'Pangéran Adipati Prawiradiningrat'.

* Joint acting wedana.

c. $1755-21$ October 1798

November 1798-20 June 1812 previously wedana of the Suranatan, of Sundanese origin. Fled back to west Java at time of British attack on kraton.

July 1812-September 1823

previously member of the Suranatan. Dismissed by Danureja IV and made the haj to Mecca in July 1825. September 1823-c. 1835

son of an ordinary priest, but married to a sister of Hamengkubuwana II's last official consort, Ratu Sultan, formerly Radèn Ayu Andayaningrat, commander of his Amazon corps. ${ }^{3}$

2 Details taken from B.Ng. I:33, VIII. 38-40; I:39, X.11; II:170-4, XLI. 1-39; BD (Manado) II:113, XIV.40; II:118, XIV.54-5; Carey 1992:116, 284, 441 note 210.

3 For a brief biography of Ratu Sultan/Radèn Ayu Andayaningrat, see Carey 1992:413 note 73. 
Patih of the Kadipatèn ${ }^{4}$

Mas Tumenggung Wiraguna c. 1780-30 April 1807

father of Radèn Tumenggung Major Wiranagara.

Married to a village woman claiming to be a descendant of Surapati. Illiterate and of village stock. Had served Hamengkubuwana I as a bupati during Giyanti War, but too uneducated to be given a high post in post-1755 Yogya administration.

Mas Tumenggung Kertadirja I 30 April 1807-died pre-1810 father of Mas Tumenggung Kertadirja II, bupati of Kerja and Masaran in Sokawati.

Mas Tumenggung Sumadirja c. 30 April 1807-died pre-1810 (bupati of Japan/Majakerta, father of Danureja IV).

*Kyai Tumenggung 1810-died pre-1812

Cakradipura

*Radèn Ngabèhi Jayasentika

1810-21 June 1812

of Madurese descent; killed on orders of Pangéran Mangkudiningrat I.

*Joint patih

Bupati wedana (nayaka) of the kraton ${ }^{5}$

1786 (Memorie of J.M. van Rhijn)

Wedana jero (Inner bupati)

Radèn Tumenggung Mangundirja

Kyai Tumenggung Mangundipura (kliwon of Danureja I, appointed 1786)

Mas Aria Mandura

Wedana jaba (Outer bupati)

Radèn Aria Sindureja

Radèn Tumenggung Natayuda I (bupati bumija, wedana of Kedhu)

Radèn Tumenggung Sumadiningrat (appointed 1794)

Radèn Tumenggung Danukusuma

Pangéran Dipakusuma (wedana gedhé prajurit; troop commander)

4 Taken from BD (Manado) II:141-2, XV. 39-41; Dj.Br. 38, M. Waterloo (Yogyakarta) to B.F. von Liebeherr (Surakarta), 30-4-1807.

5 Details taken from Rouffaer, 'Archiefstukken (diverse) over de vorstenlanden', loose notes on the 'Hoofd Regenten van Jogjakarta', and from the various Memorie van Overgave. The full number of nayaka should be 8 ( 4 inner and 4 outer), but often smaller numbers are given in the Memorie. 
1798 (Memorie of W.H. van IJsseldijk)

Wedana jero

Radèn Tumenggung Sumadiningrat (appointed 1797)

Radèn Tumenggung Purwadipura (appointed 1797)

Radèn Aria Sindureja

Mas Tumenggung Mangundipura (wedana bandar; head of tollgates)

Wedana jaba

Radèn Tumenggung Danukusuma I (kliwon of Danureja I)

Radèn Tumenggung Mertanagara (kliwon of Danureja I)

Mas Aria Mandura

Radèn Tumenggung Mertalaya (appointed 1795; grandson of

Pangéran Ngabèhi)

1803 (Memorie of J.G. van den Berg)

Wedana jero

Radèn Tumenggung Sumadiningrat

Radèn Tumenggung Purwadipura

Radèn Aria Sindureja

Mas Tumenggung Mangundipura (wedana bandar)

Wedana jaba

Radèn Tumenggung Natayuda I (bupati bumija of Kedhu, poisoned 29-11-1804)

Mas Tumenggung Sindunagara I (kliwon of Danureja II;

previously Mas Aria Mandura)

Radèn Tumenggung Natadiningrat (appointed 1805)

Radèn Tumenggung Mertalaya

1808 (Memorie of M. Waterloo)

Wedana jero

Radèn Tumenggung Sumadiningrat

(suspended March 1807-early 1808)

Radèn Tumenggung Purwadipura

(dismissed 25-11-1810)

Mas Tumenggung Mangundipura

Radèn Aria Sindureja 
Wedana jaba

1811 (Report of John Crawfurd)

Wedana jero

Wedana jaba

1816 (Report of John Crawfurd)

Wedana jero

Wedana jaba
Radèn Tumenggung Natadiningrat

(banished to Meester Cornelis, Batavia, and Cirebon, 17-12-1810 - 29-12-1811)

Mas Tumenggung Sindunagara I

(appointed Kyai Adipati Danureja III, 6-11-1811)

Radèn Tumenggung Danukusuma I (dismissed

November 1811, murdered mid-January 1812)

Radèn Tumenggung Mertalaya

Radèn Tumenggung Sumadiningrat

(killed in battle 20-6-1812)

Radèn Aria Sindureja

Radèn Tumenggung Mertalaya

Mas Tumenggung Mangundipura

Radèn Tumenggung Ranadiningrat

(wedana gedhé prajurit; kraton troop commander)

Radèn Tumenggung Danunagara (appointed

11-11-1811, served as kliwon of Danureja III)

Radèn Tumenggung Sindunagara II (appointed 2-12-1811)

Radèn Tumenggung Tirtadiwirya

Radèn Tumenggung Sasradiningrat II

Kyai Tumenggung Reksanegara (wedana bandar; head of tollgates)

Radèn Tumenggung Mertanagara II (son of Pangéran Demang by daughter of Danureja I, dismissed for corrupt practices, pre-August 1816)

Radèn Tumenggung Sasradiningrat II

Mas Tumenggung Mangundipura

Radèn Tumenggung Danunagara (kliwon of Danureja IV)

Radèn Tumenggung Sindunagara II

Mas Arya Mandura (wedana gladhag; head of porters' guild)

Radèn Tumenggung Major Wiranagara (wedana gedhé prajurit, appointed 1817) 


\section{Kapitan $\operatorname{cin}^{6}$}

To In

Gan Ke Ko

Tan Lek Ko

Qué Jin Sing

Tan Jin Sing

Qué Wi Kong

Qué Pun Sing c. $1755-1764$

$1764-1776$

1776-c. 1793

previously kapitan cina of Kedhu

c. $1793-1803$

previously kapitan cina of Kedhu.

27 September 1803-6 December 1813

son of above; previously kapitan cina of Kedhu, later Radèn Tumenggung Secadiningrat (6-12-1813), subsequently Radèn Tumenggung Purwa (31-12-1830), died 10-5-1831.

6 December 1813-20 August 1828

relation of above.

20 August 1828-?

son of above. 